\title{
Militancia femenina contra la dictadura de Pinochet: Legitimación memorística de La mujer metralleta
}

Ana Corbalán

University of Alabama

acorbalan@ua.edu

\begin{abstract}
This essay analyzes the representation of female activism in La mujer metralleta, a documentary by Chilean Francisco López Balló that reconstructs the biography of Marcela Rodríguez Valdivieso, a guerrilla who has succumbed to the oblivion in Chile. It is necessary to highlight her anti-dictatorial fight in order to recover her name and that of so many other militants. My study aims to eliminate the prevailing silence around the exiles who also contributed to the redemocratization processes in Chile and participated in the resistance against Pinochet. Despite their constant political activism, women have been excluded from official historiography. This essay claims a place in the world to one of the many activists who experienced the process of Chilean exile and whose biography
\end{abstract}


contributes to a better understanding of female activism. This documentary offers a new approach to the past is constructed that questions the relations between the State and the revolutionary position of women, despite the fact that women have historically played a marginal role in war conflicts. My paper points out the relevance of this guerrilla, how this documentary contributes to reconstructing history and how exile affects the transmission of memories.

Keywords: Chilean Exile; women activism; mujer metralleta; historical documentary; resistance against dictatorship; Pinochet; Marcela Rodríguez Valdivieso

\section{Resumen}

Basándonos en las premisas de que un documental es una herramienta persuasiva con la que posicionarse ideológicamente en torno a un aspecto del pasado, en este estudio se analizará la biografía rescatada por Francisco López-Balló sobre una mujer chilena que muestra la persistencia del activismo femenino contra la dictadura de Pinochet incluso desde fuera de los límites geográficos de su nación. La mujer metralleta, de 2008, expone elocuentemente la mitificación y demonización que experimentó la figura de Marcela Rodríguez Valdivieso, conocida como "la mujer metralleta" a consecuencia de su militancia activa en un grupo de extrema izquierda. Este documental rescata su imagen para que no caiga en los anales del olvido, porque según su realizador, era necesario hacer un homenaje que ensalzara a una figura exiliada prominente de la lucha clandestina contra el régimen de Pinochet y contra la continuidad dictatorial en democracia. La mujer metralleta constituye así una herramienta mediática y discursiva que contribuye a reflexionar sobre el pasado y posicionarse con respecto a la historia reciente chilena. Mi estudio examinará de qué forma este documental mantiene una clara agenda ideológica que se confirma en las últimas palabras estáticas que aparecen al final del filme: “Dedicado a la memoria de todos los caídos en la lucha por nuestra libertad y derecho de expresión y a quienes siguen en las prisiones, reivindicando un país sin desaparecidos ni represión militar".

Palabras clave: Exilio chileno; activismo femenino; resistencia dictadura; mujer metralleta; documental histórico; Pinochet; Marcela Rodríguez Valdivieso 
n los últimos veinte años se ha renovado el interés literario y cinematográfico hacia las dictaduras latinoamericanas más recientes con el propósito de recuperar la memoria de las personas represaliadas por los regímenes dictatoriales. Según indican Cecilia González y Aránzazu Sarría, estas representaciones memorísticas se utilizan como reflexión sobre "los discursos y las prácticas de la militancia revolucionaria de los años sesenta y setenta y el universo conceptual de las nuevas izquierdas" (9). En relación a estas premisas, varios críticos han reivindicado la importancia de la resistencia femenina contra el autoritarismo. Por ejemplo, Ariel Dorfman ha subrayado que las memorias de las mujeres contribuyen a hacer historia (2). Por su parte, Jo Fisher considera que las activistas que lideraron la militancia como mecanismo de resistencia contra las dictaduras demostraron un coraje extraordinario para confrontar la brutalidad de la represión militar (1). En la misma línea de pensamiento, Patricia Rubio afirma que: "la historiografía chilena, y en particular la del pinochetismo, no puede hacerse sin considerar en profundidad la experiencia de la mujer" (196). Al respecto, la periodista Gladys Díaz, que también estuvo exiliada y pertenecía al Movimiento de Izquierda Revolucionaria, ha propuesto que el eje de la resistencia se sitúa en tres frentes de batalla: el clandestino, el de la cárcel y el del exilio; en todos ellos las mujeres están escribiendo una página importante para conseguir un papel protagonista en la historia y liberar a la población de la represión dictatorial (33). Su manifiesto político más reconocido a nivel internacional concluye con estas palabras: "Constituimos el cincuenta por ciento, y tenemos un potencial revolucionario... No habrá jamás liberación del pueblo, si las mujeres no se unen a la lucha masivamente" (15).

Para indagar más sobre este activismo femenino se analizará en estas páginas La mujer metralleta, documental realizado por el chileno Francisco López Balló (1973-) que reconstruye la biografía olvidada de Marcela Rodríguez Valdivieso, una guerrillera que tuvo renombre en su momento por ser fotografiada en la puerta de un banco con una metralleta al hombro, aunque 
ha vivido muchos años exiliada en Italia y ha caído en el olvido. En la película se rescata su figura icónica y su militancia, que ha adquirido patrones políticos, sociales y genéricos. El presente estudio plantea, de este modo, eliminar el silencio imperante en torno a las exiliadas que también contribuyeron a los procesos de redemocratización de Chile y participaron en la lucha contra Pinochet. Pese a su constante activismo político, las mujeres han sufrido particular desatención y han sido excluidas de la historiografía oficial. Tal y como plantea Josebe Martínez, los exiliados se definen por estar "buscando un espacio para gente sin lugar" (50). Este ensayo reivindica un espacio propio y concede un lugar en el mundo a una de tantas guerrilleras olvidadas que experimentaron el proceso del exilio chileno y cuya biografía contribuye a entender mejor la militancia femenina antidictatorial.

Por medio de este documental de marcada reivindicación política se construye una nueva aproximación al pasado que cuestiona teórica y pragmáticamente las relaciones entre el Estado y la posición revolucionaria de la mujer, pese a que ésta ha ocupado en la historia un papel marginal en los conflictos bélicos (Harlow 182). Para desarrollar este análisis, se procederá a explicar cuál es la importancia de esta guerrillera, de qué forma contribuye este documental a reconstruir la historia y cómo afecta el exilio en la transmisión de memorias.

\section{¿Quién es la mujer metralleta?}

Con este apodo se conoce a Marcela Rodríguez Valdivieso (1953-) que fue miembro de la lucha armada contra la dictadura de Pinochet y se convirtió en una heroína popular tanto dentro como fuera de los límites geográficos de su nación. Sin embargo, lo único que se recuerda de esta figura histórica en la memoria cultural chilena del siglo XXI es una fotografía que la lanzó a la fama, al ser retratada con una metralleta al hombro en el asalto a un banco, imagen que la identificó como una líder del pueblo que participaba en los robos de 
bancos y en los asaltos contra los militares. Marcela militaba en una de las principales organizaciones clandestinas, el MAPU Lautaro, un grupo armado de extrema izquierda que fue desarticulado en 1993, tres años después de la llegada de la democracia. Las otras dos asociaciones eran el Movimiento de Izquierda Revolucionaria y el Frente Patriótico Manuel Rodríguez.

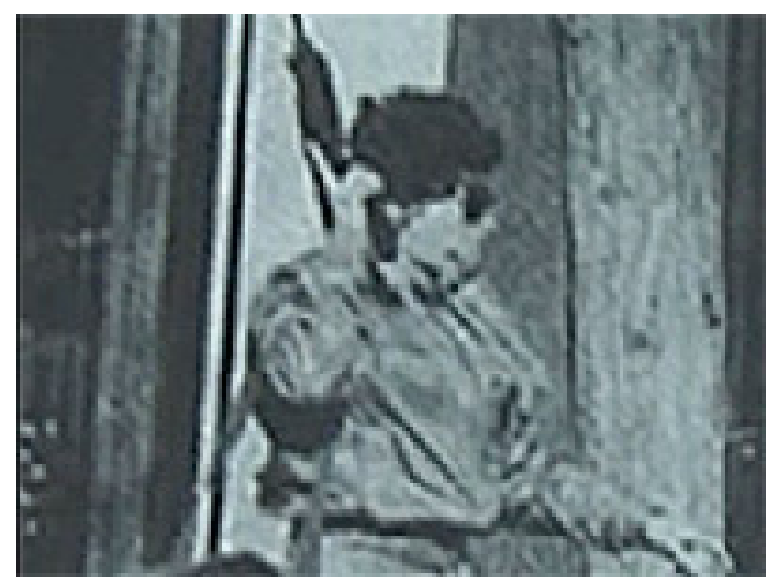

Fig 1. Foto de archivo mujer metralleta (04:34)

La protagonista del documental solamente tenía veinte años cuando ocurrió el golpe militar. En ese momento, se integró en las fuerzas juveniles de resistencia contra la dictadura. En 1990, en uno de sus enfrentamientos con la policía, mientras intentaba rescatar a un preso político, sufrió una herida de bala en la espalda que le produjo una paraplejia permanente. Fue encarcelada, juzgada y condenada a cadena perpetua por sus crímenes. Estuvo incomunicada en un hospital durante mucho tiempo, se le negó el asilo político en Noruega y como resultado de su constante activismo contra el régimen de Pinochet, ha sido idealizada por un sector de la sociedad y demonizada por otro. Su familia inició una campaña internacional para que pudiera salir del país. Lo 
logró finalmente en 2002 cuando consiguió asilo político en Italia, y desde el exilio ha continuado participando en actividades políticas para restablecer la justicia en Chile y acabar con la impunidad del régimen. Por lo tanto, en las siguientes páginas se analizará la centralización de la agencia femenina en la lucha armada, utilizando como punto de partida este documental específico que se propone legitimar tanto la resistencia política de Marcela Rodríguez como su marcado compromiso social.

\section{Aproximación a la militancia femenina}

Marcela Rodríguez ejemplifica un feminismo de la antidictadura, término que fue acuñado por Nelly Richard para definir el activismo femenino que reclama la igualdad de género y también lucha contra la subyugación política y social en las dictaduras (202). Las narrativas de resistencia no sólo realizan un análisis específico de las condiciones ideológicas y materiales que las originan, sino que también contribuyen a una narrativa más extensa. López Balló adopta una clara responsabilidad ética para salvar de su destierro a esta guerrillera exiliada, dándole un rostro visible y humano. Basándose en la violencia colectiva que surgió a raíz del golpe de Pinochet, este realizador enfatiza la agencia femenina política que emergió culturalmente en respuesta al autoritarismo de la dictadura militar.

La mujer metralleta efectúa una reflexión sobre diferentes cuestiones de la identidad y subjetividad política de una activista que, tras un tiroteo quedó parapléjica. Igualmente, explora su condición de extrañamiento, alienación, aculturación y nostalgia; factores todos ellos que contribuyen a reivindicar la dignidad de esta militante, quien por su ideología política se vio forzada a salir de Chile, sucumbiendo así en el ostracismo histórico. Como explica la voz en off del director: "el mito de la mujer metralleta surgió desde el epicentro de las poblaciones combativas de Santiago. Esta mujer apareció comandando un grupo armado surgido de las organizaciones sociales que se radicalizaron como respuesta 
a la represión militar" (06:40-06:55). En relación a la militancia política femenina en organizaciones armadas, Marta Diana ha explicado que estas mujeres "han quedado básicamente como heroínas o delincuentes, y en cualquiera de los dos casos se pierde su dimensión personal" (24). Y añade que el término guerrillera "termina por deshumanizar la figura que lo origina y aquel o aquellos portadores se transforman en un ente abstracto que evoca, según la mirada-y la ideología que anima esa mirada-sentimientos inamovibles y generalmente virulentos" (24). Por medio de este documental, López Balló reivindica la visibilidad de una militante política, presentando sus memorias con un elevado grado de idealización. De hecho, uno de los propósitos de esta realización es reclamar justicia y demostrar cómo "dicha mujer restableció una justicia social hacia los más pobres. Su principal enemigo era la dictadura" (04:36-04:42).

Según indica Pilar Calveiro, las acciones de los grupos guerrilleros consistían en realizar 'operativos de 'expropiación' de armas, dinero y documentación (asalto a bancos, camiones blindados, cuarteles, comisarías, registros civiles), acciones de propaganda armada y las llamadas operaciones de "justicia popular'” (87-88). Al respecto, Tamara Vidaurrázaga Aránguiz ratifica que “las organizaciones revolucionarias del Cono Sur latinoamericano, discursivamente estuvieron abiertas e incluso fomentaron la participación femenina entre sus filas. Sin embargo esta inclusión implicó en la práctica que estas mujeres debieron militar como un guerrillero más, obviando la especificidad de sus subjetividades marcadas por un sexo y un género" (30).

Es interesante señalar que la protagonista justifica ante la cámara los actos violentos que ejerció en sus años revolucionarios como integrante del MAPU Lautaro, puesto que como sugiere Hannah Arendt, la violencia es instrumental y racional porque resulta efectiva para conseguir un objetivo específico (79). Según defiende la propia Marcela en una de las entrevistas que concede al director del documental: "si tú haces una revolución armada, por supuesto que tienes que estar dispuesto a todo, no solamente a morirte tú, sino también 
a matar para defender tus ideales." Junto a esta apología de la violencia, es preciso extrapolar la sublevación específica de esta mujer contra un régimen militar que originó su paraplejia y su posterior exilio de las fronteras chilenas.

Por consiguiente, La mujer metralleta facilita el regreso de la historia olvidada de una de tantas mujeres que lucharon con armas bélicas contra el régimen de Pinochet. Frente al discurso oficial que catalogaba y demonizaba a ésta y otras guerrilleras como comunistas y terroristas peligrosas, el realizador consigue mostrar ante la cámara el lado humano de Marcela para que su audiencia conozca a la mujer exiliada y parapléjica que se encuentra detrás del mito de "la metralleta."

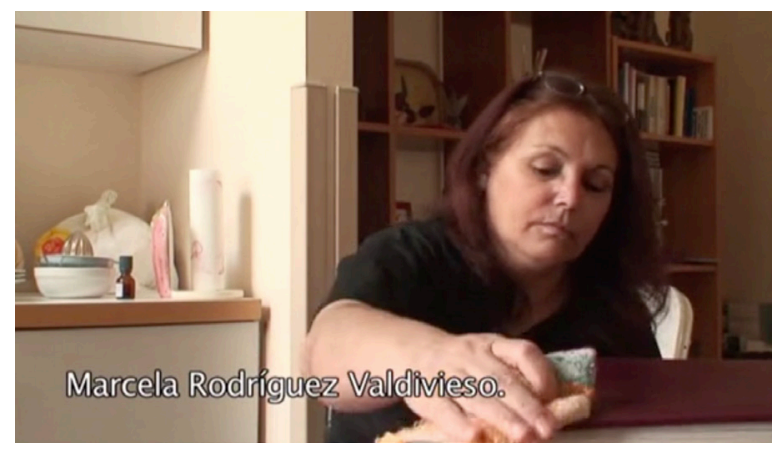

Fig 2. Humanización de la mujer metralleta (18:37)

La mujer metralleta destaca la subjetividad femenina revolucionaria que tradicionalmente ocupaba un espacio marginal en las representaciones mediáticas de la dictadura chilena y López Balló utiliza varias fuentes de evidencia que ayudan a seleccionar su contenido audiovisual, reforzando así la sensación de verosimilitud para mostrarle a su público de qué modo esta mujer ha estado luchando incansablemente contra el sistema. 


\section{El activismo político desde el exilio}

Amy Kaminsky considera el exilio como un estado de suspensión o expatriación que se asocia principalmente con lo que se deja atrás, es decir con la salida forzada de un país determinado, no con la llegada a otro lugar. Es así como la persona exiliada lleva siempre consigo algo de su pasado y de su circunstancia histórica específica, con lo cual, no puede pertenecer ni al territorio que abandona ni al nuevo al que llega. Pese a estas vicisitudes identitarias, quienes se exilian se encuentran fuertemente unidos a su país de origen para poder criticarlo y recrearlo desde un contexto internacional potencialmente liberador (30, 33). De hecho, Marcela Rodríguez es una de las más de 200.000 personas desplazadas de Chile que mantienen vivo el recuerdo del pasado dictatorial, tal y como se infiere de la narrativa de La mujer metralleta.

Resulta preciso enfatizar el desgarre de identidad que se produce como consecuencia de tener que huir y salir de un país al experimentar un estado de desarraigo originado por la ruptura forzosa y radical con el pasado. El exilio femenino adopta sus propios patrones, pues como señala Martínez, "estas mujeres son modelo de lo que fue un comportamiento de doble frente: en lo político social y en lo político sexual” (140). En esta línea discursiva, Macarena Gómez-Barris arguye que las memorias son importantes para que la situación de vivir en exilio se transforme de ser una expresión de desarraigo, nostalgia y aislamiento a posibilitar un diálogo político (136).

El campo de la biografía ha experimentado una proliferación en el siglo XXI debido a la necesidad de diversificar y ampliar el conocimiento existente sobre las dictaduras latinoamericanas. Kaminsky ya subrayó la necesidad imperiosa de recordar y recuperar las historias del exilio, las cuales incluyen narraciones de tortura, desapariciones, encarcelamiento y pérdida (After Exile xviii). En La mujer metralleta se reivindica por tanto la memoria de las mujeres que tuvieron que abandonar su país por razonas políticas y sucumbieron a un olvido historiográfico. 


\section{Un documental expositivo para rescatar a una figura histórica}

Considerando que un documental es una herramienta persuasiva con la que posicionarse ideológicamente en torno a un aspecto de la historia, la producción audiovisual que ocupa el eje de este análisis reconstruye la vida de Marcela Rodríguez Valdivieso por medio de una selección de materiales gráficos, entrevistas, fotografías, noticias televisivas y reportajes periodísticos. Al mezclar imágenes de archivo con testimonios realizados en el tiempo presente, el director expone elocuentemente la mitificación y demonización que experimentó la figura de esta activista en la memoria colectiva chilena. López Balló utiliza varias estrategias discursivas: una narración poética y evocadora, un modo expositivo para reivindicar justicia desde una mirada objetiva, una aproximación a determinados aspectos del pasado y una incitación a la empatía emocional de su audiencia. Nos encontramos ante una película marcadamente política de setenta y seis minutos de duración que recupera la historia de una de tantas mujeres injustamente silenciadas por el régimen de Pinochet.

La mujer metralleta se ajusta a las pautas que caracterizan al documental expositivo: un guion elaborado, testimonios en primera persona, efectos sonoros yuxtapuestos con comentarios de personas expertas y autoridades en el campo y una aparente objetividad que hace que el pasado histórico se transforme en presente. Para Bill Nichols, la modalidad expositiva es una forma de dirigirse al espectador directamente, con subtítulos o voces en off que proponen una determinada perspectiva, defienden una posición argumentativa y reconstruyen la historia con un tono neutral y profesional para transmitir una sensación de credibilidad, distancia, neutralidad y omnisciencia: “The voice-over commentary seems literally 'above' the fray; it has the capacity to judge actions in the historical world without being caught up in them. The professional commentator's official tone, like the authoritative manner of news anchors and reporters, strives to build a sense of credibility from qualities such 
as distance, neutrality, disinterestedness, or omniscience" (107).

La mujer metralleta destaca por su hibridez al intercalar opiniones personales con imágenes de archivo, fotos, titulares de periódicos de la época, grabaciones fílmicas y entrevistas a diferentes participantes; lo cual facilita un campo más amplio de interpretación que aumenta la evidencia histórica, audiovisual, memorística y discursiva. Nichols subraya que un documental estimula en su audiencia la epistefilia; es decir, el deseo de saber, ya que conlleva una lógica informativa, una retórica persuasiva o una poética conmovedora que garantiza más información y conocimiento (40). Francisco López Balló confirma esta intencionalidad epistemológica, puesto que su locución reconoce que "la mujer metralleta" se había convertido en un fantasma de su pasado, una imagen mediática de una mujer combatiente. Su voz poética transmite así la tonalidad afectiva que define los siguientes minutos de la cinta. La voz en off del comentarista resulta significativa para la comprensión de las actividades clandestinas llevadas a cabo por la militante chilena que ocupa el eje central de su reportaje. Al utilizar las técnicas que caracterizan a los documentales expositivos, el director organiza unas imágenes que sirven de apoyo a sus palabras y las dota de sentido, enfatizando así su significado político y su apariencia de objetividad. Dicho posicionamiento ensalzador se superpone al argumento central y consigue guiar a sus espectadores por algunos recovecos del pasado seleccionados para efectuar el homenaje que merece esta activista.

Los créditos iniciales comienzan con una tonalidad en color sepia y esta iluminación se repite frecuentemente a lo largo del documental para transportar a sus espectadores a un tiempo pasado que es nebuloso. En los primeros minutos se utiliza una cámara manual que enfoca mediante planos panorámicos unas vistas aéreas de las montañas de Chile desde un avión y unos flashbacks a la infancia del narrador, cuyo rostro permanece detrás de la cámara en todo momento. 


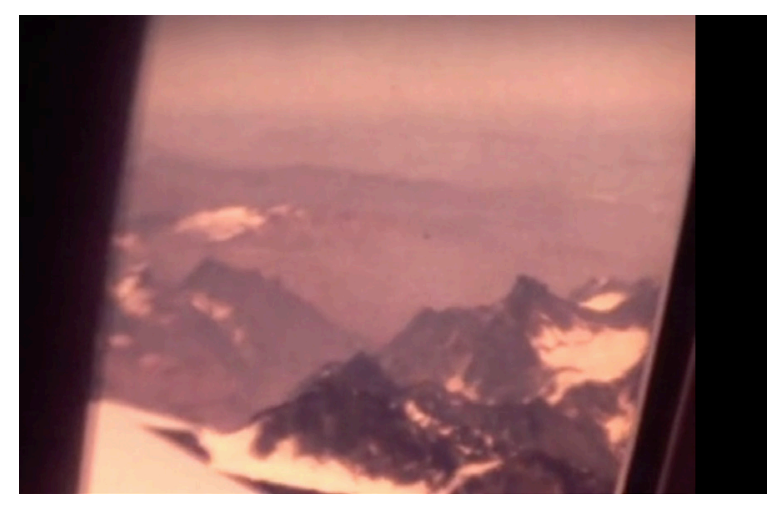

Fig 3. Imagen aérea de Chile (00:25)

La primera frase que se escucha de la voz del comentarista es: “Imágenes, recuerdos, de un país lejano" (0:48-52). De este modo, la investigación realizada por López Balló consigue reconstruir el pasado a través de su significación histórica para facilitarle a su audiencia una determinada información que permanecería inaccesible de otro modo. El documental incorpora frecuentemente una música extradiegética que se utiliza para cambiar la escenografía y yuxtaponerla a numerosos informes noticieros que acentúan su propósito reivindicativo. Asimismo, incluye en su reportaje una serie de imágenes retransmitidas por los medios de comunicación de la época, las cuales son mediáticas del estado de terror de la dictadura chilena, contribuyendo a través del metraje de archivo a transmitir la historia a una audiencia contemporánea.

\section{El acto de recordar por medio del documental}

Elizabeth Jelin ha propuesto que desenterrar la memoria en los países posdictatoriales es un acto político, porque al recordar se ejerce una reivindicación en nombre de las víctimas de la represión: “El espacio de la memoria es entonces un espacio de lucha política, y no pocas veces esta 
lucha es concebida en términos de la lucha 'contra el olvido:' recordar para no repetir" (6). Al respecto, Jean Franco considera que la amnesia es la condición que impera en la sociedad moderna, por lo que el énfasis en la historia y la memoria es primordial para combatir el olvido (Decline 12). Este documental merece ser estudiado, puesto que informa a su audiencia sobre una biografía con valor político, redescubriendo las huellas de una mujer militante que ha sucumbido al olvido de la memoria colectiva de Chile. Resulta necesario destacar su lucha antidictatorial con el propósito de recuperar su nombre y el de tantas otras militantes olvidadas.

El realizador se dirige a una audiencia internacional desde Italia, país en el que reside Marcela y desde donde le concedió las entrevistas que constituyen su testimonio en primera persona. Mientras se enfoca a la protagonista en planos medios con una cámara estática, escuchamos las preguntas que la voz del director realiza detrás de la cámara y, aunque nunca llega a vislumbrarse su rostro en la pantalla, su omnipresencia se percibe mediante las locuciones, comentarios, recuerdos y pensamientos que comparte con el público. La mujer metralleta logra recuperar así la memoria de esta figura de la resistencia para hacerla más accesible hoy en día. López Balló explica detalles de su biografía a un público no familiarizado con su historia y utiliza fragmentos de la vida de Marcela con el objetivo de combatir el ostracismo histórico al que sucumbió. Asimismo, le concede un rostro humano y personalizado a la militancia política femenina y destaca de qué forma las guerrilleras ocuparon el espacio público tras el golpe de estado de Pinochet. Su producción se convierte así en un archivo audiovisual de memorias que ha sido filmado para crear espacios en los que la violencia política se pueda aproximar a la memoria colectiva de forma significativa (Gómez-Barris 106). A través de una elaborada combinación de documentación estética y una representación de los eventos históricos específicos de Chile, López Balló acerca el pasado al presente en un documental cargado de emoción, y aunque efectúa algunas simplificaciones 
en el retrato realizado sobre la vida de Marcela, logra humanizar a una persona acusada de radicalismo militar.

Jacques Derrida define a los fantasmas como materializaciones de aquellos que han sido excluidos de la historia, aunque estos espectros del pasado, tarde o temprano se hacen presentes y nos ofrecen la oportunidad de aceptarlos para acogerlos en la memoria y otorgarles la justicia que merecen (175). Avery Gordon propone a su vez el tropo de haunting como: "a story about what happens when we admit the ghost-that special instance of the merging of the visible and the invisible, the dead and the living, the past and the present-into the making of worldly relations and into the making of our accounts of the world" (24). De esta forma, Francisco López Balló efectúa una llamada al reconocimiento ético que intenta dirigirse a las figuras fantasmagóricas del pasado al enfatizar su presencia constante y su negativa a desvanecerse en el olvido. La mujer metralleta indaga en los espacios de la memoria para recuperar las sombras de una mujer que luchó activamente contra la dictadura de Pinochet y llegó a ser temida por su militancia, por su condición de guerrillera y por personificar auténticos territorios de resistencia armada frente al régimen; ya que como bien indica Colin Davis, los espectros no están ni presentes ni ausentes, ni muertos ni vivos (373).

Esta película rescata así unas voces de los fantasmas del pasado. Gordon sugiere que la recuperación de estas historias caídas en el olvido sirve para reparar errores representativos y para entender las condiciones que produjeron ciertas memorias específicas con el propósito de elaborar otras memorias alternativas en el futuro (22). Dicho objetivo se observa ya desde una de las primeras secuencias, cuando se escucha la voz en off de Francisco López Balló reconociendo que los espectros adquieren formas humanas y que él se había propuesto indagar sobre estas sombras con las que había crecido. A su vez, reitera que Marcela permanece en su memoria como una "heroína popular" y que decidió hacer este reportaje sobre ella porque "su espíritu flotaba aún 
entre las mujeres anónimas, llevaba en sus cabellos el viento de la subversión y de la justicia social." Mediante la idealización de una militante contra la dictadura, esta producción audiovisual contribuye a recuperar las huellas de los fantasmas que regresan para exigir una reparación en el sentido estipulado por Jo Labanyi; es decir, para que su nombre, en vez de ser borrado, sea ensalzado (66). Así, La mujer metralleta rescata la imagen y la biografía de Marcela Rodríguez Valdivieso para que no caiga en la amnesia histórica, porque según indica la voz en off de López Balló, era necesario hacer un homenaje audiovisual que ensalzara a una figura exiliada prominente de la lucha clandestina contra el régimen de Pinochet y contra la continuidad dictatorial en democracia.

La mujer metralleta es una narrativa de la memoria que resulta necesaria en una sociedad en la que prima el olvido. Este documental transmite unas memorias de carácter transgeneracional a una audiencia que, a diferencia de su director, no experimentó necesariamente la represión del Pinochetismo. En principio, la voz autorial comunica al espectador que él nació prácticamente a la vez que el golpe de estado de Pinochet y que sus recuerdos sobre los eventos siempre han sido borrosos y han estado mediatizados por los medios de comunicación. Es preciso señalar que López Balló pertenece a la generación de los hijos de la dictadura y su producción está caracterizada por "la mezcla entre los ámbitos privado y público, íntimo y político," en los que "se observa una politización de lo familiar y una familiarización de lo político" (Duperron y Todeschini 326). El director creció en el corazón de la dictadura y vivió durante los eventos traumáticos que agitaron la historia de Chile, pero era muy pequeño para luchar contra el régimen. Él conoce los hechos gracias a la posmemoria, que según Marianne Hirsch, "strives to reactivate and reembody more distant social/national and archival/cultural memorial structures by reinvesting them with resonant individual and familial forms of mediation and aesthetic expression" (111). Al no recordar la dictadura nítidamente, tiene que utilizar archivos históricos para responder al imperativo ético de recuperar 
los silencios que marcaron su infancia y juventud. Su cámara permite que el público reconstruya unas memorias incompletas del pasado, aproximándolas de este modo al contexto presente. Es más, mediante el uso de una estructura temporal progresiva que señala los sucesivos encuentros del investigador con la protagonista de su historia durante las cuatro estaciones del año, el documental adopta una técnica cronológicamente lineal con el objetivo de facilitar que su audiencia siga de forma estructurada el argumento central de la cinta.

Como es sabido, la posmemoria es la relación de la segunda generación con ciertas experiencias traumáticas del pasado que fueron transmitidas a esta generación tan profundamente que se han convertido en memorias por sí mismas (Hirsch 103). Por consiguiente, para lograr establecer pinceladas de la memoria colectiva chilena es preciso recuperar tanto la voz de esta militante como la del resto de la población que experimentó la represión de Pinochet. Mediante esta producción cinematográfica se contribuye a reconstruir un pasado nebuloso y plagado de silencios. De hecho, La mujer metralleta permite que las personas que vivieron la dictadura chilena compartan su historia con aquéllas que sufrieron sus consecuencias y con aquéllas que desconocían estos eventos. Según indica Andreas Huyssen, toda representación del pasado está basada en la memoria, pero a su vez, la memoria se articula a través de su propia elaboración. Por tanto, el pasado no está simplemente anclado en los recuerdos, sino que también debe ser articulado para lograr recrear unas determinadas memorias (2-3).

Este documental suscita memorias prostéticas; es decir, memorias que surgen, en palabras de Alison Landsberg, a raíz de la relación empática de las personas con un pasado colectivo que no han experimentado de forma personal y pueden surgir simplemente durante el visionado de una película. Landsberg sugiere que a raíz de la experiencia fílmica la audiencia se sumerge en unas historias que le afectan de forma personal y alteran su capacidad 
empática: “'Prosthetic memories' are felt experiences of events we have not lived but that we take on through our emotions and our bodies when we view a powerful media drama or interact with a well-designed historical exhibit" (10). La mediación audiovisual nos ayuda de este modo a rescatar de los archivos la biografía de esta exiliada política, recreando sus vicisitudes durante la dictadura de Pinochet y acercándonos a una etapa que de otro modo resultaría muy lejana.

Como bien apunta Gómez-Barris, los documentales pueden romper el silencio y el aislamiento al compartir experiencias individuales traumáticas con un grupo: "Making survivors' stories publicly available in the technological format of documentary unsettles what is known or imagined about the past, and what is silenced or shut down" (130). Efectivamente, por medio de esta producción audiovisual, el activismo de Marcela cobra vida ante la memoria colectiva y constituye una herramienta política para reflexionar sobre el pasado y posicionarse ideológicamente en relación a la historia reciente chilena.

Nina Gilben Seavey ha propuesto que el documental histórico se basa en hechos reales y utiliza evidencia empírica que abre una ventana a los espacios, tiempos, eventos y personas del pasado para ofrecer una mirada más amplia de la historia que la ofrecida tradicionalmente por los historiadores (119). Robert Rosenstone añade al respecto que los documentales nunca reflejan la realidad, sino que la recrean. Para él, su aparente autenticidad radica en la capacidad que tienen de vislumbrar directamente el pasado. No obstante, esta mirada constituye su principal peligro, ya que pese al uso de fotografías y artefactos reales que transmiten una visión realista del momento histórico, la pantalla no retrata los eventos en sí, sino tan sólo representaciones selectivas de unos acontecimientos cuidadosamente organizados en secuencias históricas que justifican un argumento específico (36).

Esta manipulación discursiva es notable en la producción de López Balló, puesto que a pesar de su aparente objetivismo y distanciamiento crítico, 
consigue que su audiencia sienta empatía hacia esta mujer. En relación a la nostalgia, Pam Cook ha mostrado a su vez que las reconstrucciones fílmicas del pasado contribuyen a desarrollar una relación personal y subjetiva entre el espectador y la historia, provocando así unas respuestas afectivas que nos informan de las conexiones entre el presente y el pasado (2-3). Es así como mediante la música, las fotografías de la infancia de Marcela y la abundancia de primeros planos en las entrevistas realizadas, este documental adopta una tonalidad melancólica que contribuye a reforzar dicha empatía.

\section{Historia a través de las imágenes}

En este sentido, se debe hablar de "historiofotía," término acuñado por Hayden White para indicar el uso de la imagen como evidencia histórica; es decir, la representación de la historia y de nuestro pensamiento sobre la misma mediante imágenes visuales y fílmicas (1193). Según White, gran parte de la información sobre el pasado solamente se puede obtener a través de los medios audiovisuales, por lo que el cine resulta más adecuado que el discurso escrito para representar ciertos tipos de fenómenos históricos, tales como paisajes, ambientes, emociones, escenas y complejidades contextuales (119394). De hecho, la historiofotía es especialmente relevante en el documental que nos ocupa, ya que la biografía de Marcela Rodríguez se va descubriendo a través de las imágenes y entrevistas audiovisuales facilitadas por López Balló mediante la yuxtaposición de imágenes de archivo con entrevistas realizadas en el presente. Esta interacción del testimonio oral y directo de Marcela con los metrajes de archivo y otros informes periodísticos completa un mosaico que da cuenta de la vida de una militante armada tanto en Chile como en el exilio. 


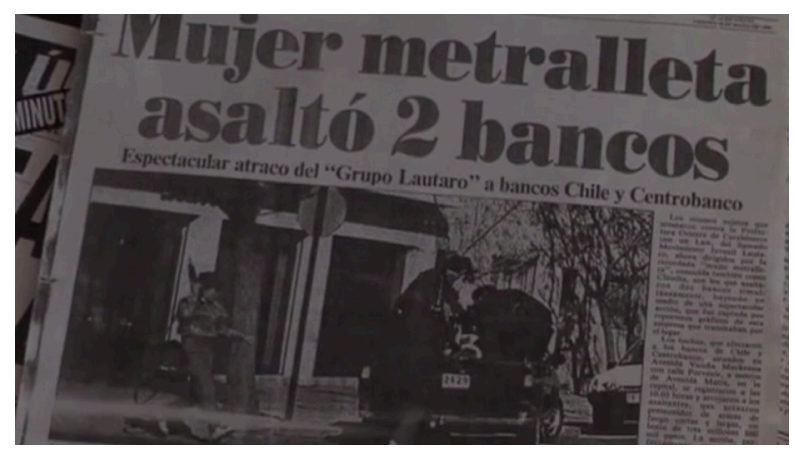

Fig 4: periódico de la época (16:27)

El metraje de imágenes, especialmente de fotografías, sirve para otorgar más autenticidad al documental. Igualmente, los materiales reales de archivo que utiliza López Balló contribuyen a reforzar la apariencia de verosimilitud en su reconstrucción del pasado. Es así como se produce una translucidez audiovisual en la medida en que la rápida superposición de las diferentes imágenes y sonidos no permiten percibir de manera nítida toda la biografía de la mujer homenajeada en esta producción, sino la selección de retazos de la misma que su director muestra al espectador. El director ejerce una validación de los registros históricos mediante los archivos periodísticos, fotográficos y fílmicos. Esta recomposición del pasado evidencia el poder de las imágenes visuales, las cuales sirven para reforzar los comentarios ofrecidos por la voz en off dominante en la diégesis del filme.

La voz narrativa de López Balló permanece detrás de la cámara en todo momento. Su función consiste en entrevistar a testigos presenciales o informados que subrayan las variadas interpretaciones de la historia y de la memoria y así les concede más autoridad al exponer directamente sus voces y rostros ante la cámara. Con estas estrategias, los espectadores se encuentran ante una sobria producción cuyo objetivo es documentar testimonios directos y relevantes sobre la historia silenciada de la dictadura de Pinochet, yuxtaponiendo 
imágenes históricas de archivo con un enfoque en primer plano a las personas entrevistadas. Esta mirada en close-up se observa desde la primera vez que la audiencia escucha la voz de Marcela, cuya expresión facial se enfoca desde una toma estática, lo cual sirve para humanizar a esta persona que comparte ante la cámara unas fotografías de su infancia mientras le explica tranquilamente a su interlocutor que nunca había tenido un apodo, que la llamaban Marcelita y que era una niña normal. Ella misma reitera esta idea una y otra vez: "yo era una mujer normal, hasta el 11 de septiembre del 73 , yo era una mujer normalísima" (24:14-18). Las imágenes que se muestran de la protagonista adoptan una función primordial en el documental, ya que contradicen la violencia asociada tradicionalmente con su figura, siempre visualizada en los medios de comunicación con una metralleta al hombro. Junto a esta imagen violenta, las fotografías de su infancia, que aparecen en una tonalidad en color sepia, se utilizan como fragmentos de una vida congelada del pasado. De esta forma, la cámara yuxtapone titulares en el periódico junto a retratos de su niñez para que Marcela deje de ser clasificada como un monstruo o una heroína en la memoria colectiva chilena. Estos encuentros audiovisuales de la audiencia con la protagonista facilitan nuestro acercamiento a una persona cuyos vagos recuerdos la asemejaban a un espectro del pasado que había sido ignorado hasta el momento. Mediante las entrevistas se muestra la cohesión existente en la polifonía de voces que ayudan a redescubrir el mito creado en torno a la "mujer metralleta." Asimismo, esta fragmentación de imágenes de la vida de Marcela compone una pequeña representación de lo que supone la retórica de la resistencia femenina contra la dictadura de Pinochet.

En realidad, la agenda política de Francisco López Balló se hace transparente en varias ocasiones, como sucede en una secuencia que enfoca sin ningún tipo de sonido diegético o extradiegético la tumba de Salvador Allende, de la que cuelga una bandera chilena, y el ángulo contrapicado de la cámara hace zoom en el siguiente mensaje: "ni olvido, ni perdón." 


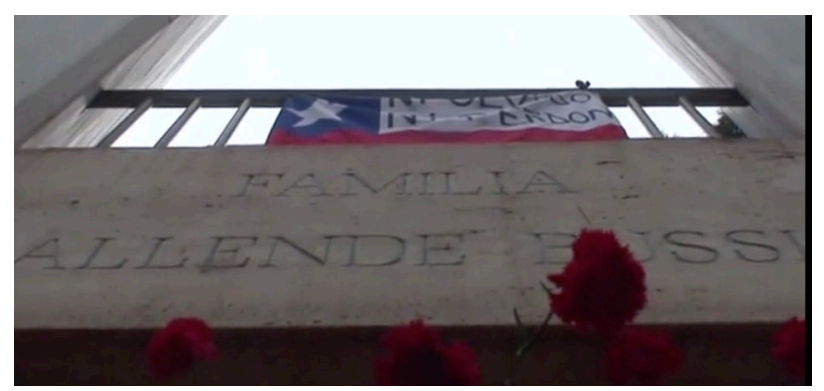

Fig 5: Tumba de Salvador Allende (1:11:01)

Su marcada ideología en defensa de la resistencia efectuada por Marcela se confirma en las últimas palabras que aparecen sobre una pantalla negra y estática con el sonido diegético del mar en los créditos finales, al ratificar la intencionalidad del director de homenajear a las víctimas de la dictadura: “Dedicado a la memoria de todos los caídos en la lucha por nuestra libertad y derecho de expresión y a quienes siguen en las prisiones, reivindicando un país sin desaparecidos ni represión militar" (1:13:20). De esta forma, La mujer metralleta consigue su principal objetivo: que la sociedad internacional sepa lo que ocurrió en Chile y que no se olviden estos atentados contra los derechos humanos.

\section{Conclusiones: hacia una reescritura de la historia}

En definitiva, La mujer metralleta sirve como ejemplificación de la fragmentación de memorias selectivas que componen una pequeña representación de lo que supone la retórica de la resistencia de una mujer exiliada. Igualmente, la pantalla refleja la expresión de la propia subjetividad femenina como instrumento que sirve para denunciar el exilio de una colectividad que tuvo que perder sus raíces abriendo brechas en sus relaciones personales y sociales. Mediante su documental, Francisco López Balló le hace justicia a Marcela Rodríguez Valdivieso para legitimar su autoridad como testigo presencial de la 
resistencia contra la dictadura de Pinochet.

Primordialmente, este documental es un producto estético que aumenta la concienciación social y contribuye a cerrar y a sanar las cicatrices de la historia. Marcela Rodríguez Valdivieso ejemplifica el activismo y la lucha femenina contra el régimen de Pinochet, recuperando una página de la historia que fue arrancada de raíz. López Balló demuestra con su documental que los fantasmas de la dictadura están más presentes que nunca, por lo que la urgencia de recuperar estas experiencias se transmite mediante memorias prostéticas al espectador contemporáneo. Su realización también puede interpretarse como un homenaje a tantas mujeres que no tuvieron la oportunidad de hablar y fueron silenciadas durante el Pinochetismo.

Finalmente, por medio del énfasis en una militancia femenina, se rescatan en este documental las voces silenciadas de un pasado plagado de olvidos historiográficos. La mujer metralleta reivindica asi la importancia de unas mujeres cuya representación había sido omitida por la historiografía oficial, pese a que destacaron por su resistencia activa contra las dictaduras. Estas producciones audiovisuales indagan en los espacios de la memoria para recuperar las sombras de aquellas mujeres que lucharon por defender su ideología política, llegando a constituir auténticos territorios de disidencia. Por último, es preciso reiterar que los documentales históricos como el que aquí se ha analizado contribuyen a dar un rostro visible y humano al activismo femenino antidictatorial que se llevó a cabo desde el frente del exilio, reclamando así un espacio que había sido negado a la gente sin lugar. 


\section{Obras citadas}

Arendt, Hannah. On Violence. Harcourt, Brace \& World, 1969.

Calveiro, Pilar. Política y/o violencia: Una aproximación a la guerrilla de los años setenta. Siglo XXI Editores, 2013.

Cook, Pam. Screening the Past: Memory and Nostalgia in Cinema. Routledge, 2005.

Davis, Colin. “État Présent: Hauntology, Spectres and Phantoms.” French Studies, vol. 59, no. 3, 2005, pp. 373-79.

Derrida, Jacques. Specters of Marx: The State of the Debt, the Work of Mourning, and the New International. Traducido por Peggy Kamuf, Routledge, 1993.

Diana, Marta. Mujeres guerrilleras: La militancia de los setenta en el testimonio de sus protagonistas femeninas. Planeta Argentina, 1996.

Díaz, Gladys. "Roles y contradicciones de la mujer militante en la resistencia y en el exilio." Women's International Resource Exchange Service, 1979.

Dorfman, Ariel. "Código politico y código literario: el género testimonio en Chile hoy." Testimonio y literatura, editado por René Jara y Hernán Vidal, Institute for the Studies of Ideologies and Literature, 1986, pp. 170-234.

Duperron, Celia y Lolita Todeschini. "Pasaje de vida: memoria y representación de la militancia de los padres." Militancias radicales: Narrar los sesenta y setenta desde el siglo XXI, editado por Cecilia González y Aránzazu Sarría Buil, Postmetropolis Editorial-Prohistoria Ediciones, 2016, pp. 317-36.

Fisher, Jo. Out of the Shadows: Women, Resistance and Politics in South America. Latin America Bureau, 1993.

Franco, Jean. Marcar diferencias, cruzar fronteras. Editorial Cuarto Propio, 1996.

- The Decline and Fall of the Lettered City: Latin America in the Cold War. Harvard UP, 2002.

Gilden Seavey, Nina. "Film and Media Producers: Taking History off the Page and Putting It on the Screen." Public History: Essays from the Field, editado por James B. Gardner y Peter S. LaPaglia, Krieger Publishing Company, 1999, pp. 117-28.

Gómez-Barris, Macarena. Where Memory Dwells: Culture and State Violence in Chile. U of California P, 2009.

González, Cecilia, y Aránzazu Sarría Buil, editores. Militancias radicales: Narrar los sesenta y setenta desde el siglo XXI, Postmetropolis Editorial-Prohistoria Ediciones, 2016. 
Gordon, Avery F. Ghostly Matters: Haunting and the Sociological Imagination. U of Minnesota P, 1997.

Harlow, Barbara. Resistance Literature. Methuen, 1987.

Hirsch, Marianne. "The Generation of Postmemory." Poetics Today, vol. 29, no. 1, 2008, pp. 103-28.

Huyssen, Andreas. Twilight Memories: Marking Time in a Culture of Amnesia. Routledge, 1995.

Jelin, Elizabeth. Los trabajos de la memoria. Siglo Veintiuno, 2002.

Kaminsky, Amy. Reading the Body Politic: Feminist Criticism and Latin American Women Writers. U of Minnesota P, 1993.

—. After Exile: Writing the Latin American Diaspora. U of Minnesota P, 1999.

La mujer metralleta. Dirigido por Francisco López-Balló, producido por Micromega Visa, 2008.

Labanyi, Jo. "History and Hauntology; or, What Does One Do with the Ghosts of the Past? Reflections on Spanish Film and Fiction of the Post-Franco Period." Disremembering the Dictatorship; The Politics of Memory in the Spanish Transition to Democracy, editado por Joan Manuel Resina, Rodopi, 2000, pp. 65-82.

Landsberg, Alison. Prosthetic Memory: The Transformation of American Remembrance in the Age of Mass Culture. Columbia UP, 2004.

Martínez, Josebe. Exiliadas: Escritoras, Guerra civil y memoria. Montesinos, 2007.

Nichols, Bill. Introduction to Documentary. Indiana UP, 2001.

Richard, Nelly. Residuos y metáforas (ensayos de crítica cultural sobre el Chile de la Transición). Editorial Cuarto Propio, 1998.

Rodríguez, Marcela. “Testimonio personal de Marcela Rodríguez.” octubre 1999, www. carlos.marighella.nom.br/testigo.htm.

Rosenstone, Robert A. "History in Images/History in Words." The History on Film Reader, editado por Marnie Hughes-Warrington, Routledge, 2009, pp. 30-41.

Rubio, Patricia. “Lavando la esperanza y Volver a empezar: Muestras del testimonio femenino chileno." El testimonio femenino como escritura contestataria, editado por Emma Sepúlveda Pulvirenti y Joy Logan, Asterión, 1995, pp. 177-97.

Vidal, Hernán. Política cultural de la memoria histórica: Derechos humanos y discursos cuturales en Chile. Mosquito Editores, 1997. 
Vidaurrázaga Aránguiz, Tamara. "Subjetividades sexo genéricas en mujeres militantes de organizaciones político-militares de izquierda en el Cono Sur." Revista de Estudios de Género: La Ventana, 2015, vol. 5, no. 41, pp. 7-34.

White, Hayden. "Historiography and Historiophoty." American Historical Review, vol. 93, no. 5, 1988, pp. 1193-99. 